\title{
Contemporary surgical treatment of benign prostatic hyperplasia
}

\author{
Ricardo Luís Vita Nunes ${ }^{1 *}$, Alberto Azoubel Antunes², Davi Souza Constantin ${ }^{3}$ \\ ${ }^{1}$ Head of the Benign Prostatic Hyperplasia Department, Sociedade Brasileira de Urologia (SBU). Assistant Physician, Division of Urology, Hospital das Clínicas da Faculdade de Medicina da Universidade de São Paulo \\ (HC-FMUSP). Head of the Urology Clinic, Hospital Militar de Área de São Paulo - Exército Brasileiro, São Paulo, SP, Brazil \\ ${ }^{2}$ Associate Professor, Division of Urology. Head of the Urology Graduate Program, and Coordinator of the Prostate Sector, Division of Urology, FMUSP, São Paulo, SP, Brazil \\ ${ }^{3}$ Preceptor of Urology, Centro de Referência do Homem do Hospital de Transplantes Euryclides de Jesus Zerbini. MD, Urologist, Hospital Militar de Área de São Paulo - Exército Brasileiro, São Paulo, SP, Brazil
}

Study conducted at Urology Clinic, Hospital das Clínicas da Faculdade de Medicina da Universidade de São Paulo, and at Urology Clinic, Hospital Militar de Área de São Paulo - Exército Brasileiro, São Paulo, SP, Brazil

Article received: $7 / 3 / 2017$ Accepted for publication: $7 / 21 / 2017$

*Correspondence: Address: Av. Angélica, 672, cj. 22, Santa Cecília

São Paulo, SP - Brazil Postal code: 01228-000 rcnunes2003@yahoo.com.br

\section{SUMMARY}

Benign prostatic hyperplasia (BPH) is a common condition in adult men and its incidence increases progressively with aging. It has an important impact on the individual's physical and mental health and its natural progression can lead to serious pathological situations. Although the initial treatment is pharmacological, except in specific situations, the tendency of disease progression causes a considerable portion of the patients to require surgical treatment. In this case, there are several options available today in the therapeutic armamentarium. Among the options, established techniques, such as open surgery and endoscopic resection using monopolar energy, still prevail in the choice of surgeons because they are more accessible, both from a socioeconomic standpoint in the vast majority of medical services and in terms of training of medical teams. On the other hand, new techniques and technologies arise sequentially in order to minimize aggression, surgical time, recovery and complications, optimizing results related to the efficacy/safety dyad. Each of these techniques has its own peculiarities regarding availability due to cost, learning curve and scientific consolidation in order to achieve recognition as a cutting-edge method in the medical field. The use of bipolar energy in endoscopic resection of the prostate, laser vaporization and enucleation techniques, and videolaparoscopy are examples of new options that have successfully traced this path. Robot-assisted surgery has gained a lot of space in the last decade, but it still needs to dodge the trade barrier. Other techniques and technologies will need to pass the test of time to be able to conquer their space in this growing market.

Keywords: benign prostatic hyperplasia, surgical treatment, minimally invasive techniques, laser, videolaparoscopic, robot-assisted surgery, bipolar.

\section{INTRODUCTION}

Benign prostatic hyperplasia (BPH) is a common condition in adult men, with a tendency to progress with aging and which, in most cases, causes lower urinary tract symptoms (LUTS), with a prevalence of around $30 \%$ in individuals over 50 years. It leads to important impacts on physical and mental health. ${ }^{1,2}$ The treatment of LUTS due to infravesical obstruction secondary to BPH is constantly evolving. Therapeutic modalities for moderate and severe conditions begin with pharmacological treatment and may progress to minimally invasive, laparoscopic, robot-assisted or open surgical alternatives. ${ }^{3}$ The objective of this review is to present the entire surgical treatment program that has some scientific support, as well as new modalities that are starting to be practiced.

\section{Transurethral RESECTION OF the PROSTATE}

Until recently, monopolar transurethral resection of the prostate (M-TURP) was considered a gold standard for the treatment of prostates with a volume lower than 80 $\mathrm{cm}^{3}$ due to its effectiveness and low cost. ${ }^{47}$ However, this established technique is associated with some relevant complications, such as urethral stenosis, bleeding, bladder neck sclerosis and especially post-TURP syndrome, due to the need for hypotonic infusion fluid to avoid electrical conduction. Post-TURP syndrome consists of water intoxication alongside hyponatremia, and can lead to the occurrence of cerebral edema. ${ }^{8}$

The incorporation of bipolar technology (B-TURP) represents a significant evolution in the TURP technique in recent years. B-TURP presents a considerable advantage 
given the fact that it can be performed with normal saline solution, with excellent results in relation to a greater volume of resection within the same surgical time., ${ }^{9,10}$

In a recent prospective randomized clinical trial (RCT) comparing M-TURP with B-TURP, 497 patients with a mean age of 67.4 years and a prostate volume of $54 \mathrm{~cm}^{3}$ were divided into the two groups and monitored for 36 months. There was no statistical difference in the parameters of surgery time, catheterization time, PSA drop, peak flow improvement (Qmax), occurrence of urinary retention, and IPSS and quality of life (QoL) scores. On the other hand, B-TURP proved to be superior to M-TURP in relation to hospitalization time, blood transfusion rate, post-TURP syndrome, serum sodium rate and lower occurrence of urethral stenosis. ${ }^{11}$

In a systematic review and meta-analysis evaluating the efficacy (Qmax and IPSS) and safety of the two techniques, 31 RCTs with 3,669 patients were included..$^{12}$ Regarding efficacy, relevant clinical differences in the Qmax were observed in favor of B-TURP. Regarding safety, the almost non-occurrence of post-TURP syndrome and the low incidence of clot retention, urethral stenosis and bladder neck sclerosis have recently favored a greater use of B-TURP compared with M-TURP, resulting in its recent inclusion as the first line of treatment for enlarged prostates in the current guidelines of the European Association of Urology (EAU). ${ }^{13}$

\section{GreenLight XPS (GL-XPS) Photoselective Vaporization of the Prostate - NE 1 GR A}

The modern GreenLight system with an LBO crystal adaptation to the Nd:YAG system was released in 2006, after a redesign of the laser generator. With a wavelength of $532 \mathrm{~nm}$ (using oxyhemoglobin as chromophore), it was initially defined as a high power system (HPS), which had a $120 \mathrm{~W}$ output and was often referred to as photovaporization of the prostate. ${ }^{14}$ Its latest generation, the XPS system is capable of generating $180 \mathrm{~W}$ of high frequency pulses of laser energy in a wider beam, improving vaporization efficiency. Hueber et al. ${ }^{15}$ evaluated the surgical performance of the GL-XPS system compared with the old HPS system in 1,809 patients in seven international centers. The new system has significantly reduced laser and operative time. The number of fibers used during the procedure was significantly reduced using the XPS system, while the total energy used was also lower. They concluded that the GL-XPS demonstrates significant advantages over HPS regardless of prostate size for all operative parameters.

In a prospective randomized controlled trial comparing TURP with the GL-XPS laser system, with two years of follow-up, 29 centers were included in nine European countries involving 281 patients with BPH. There was no change in IPSS and Qmax between groups. The proportion of patients without complications during 24 months was $83.6 \%$ for GL-XPS versus $78.9 \%$ for TURP. Reductions in PV and PSA were similar in both branches and maintained throughout the study. Compared with the first year of the study, few adverse events or retreatment were reported in any of the groups, thus showing the similar efficacy and safety between the two techniques. ${ }^{16}$

Although its short- and medium-term efficacy for small and medium adenomas is well established, there is limited evidence on the use of GL-XPS laser in very large prostates. Recently, the safety and efficacy of the GL-XPS system has been demonstrated using a vapoenucleation technique in prostate glands measuring more than 150 $\mathrm{mL}$. They included 70 patients with a mean prostate size of $202 \mathrm{~mL}$ (152-376 mL), 59\% of which were using a permanent preoperative catheter. The mean surgical time was 180 minutes and an average of three fibers were used per case. The mean length of stay and catheterization time was one day. The IPSS and QoL scores improved from 16 to 3.5 and from 4 to 1 in 24 months, respectively. At 12 months, Qmax and post-void residual test (PVR) improved from 10.1 to $22.4 \mathrm{~mL} / \mathrm{s}$ and from 84 to $31.4 \mathrm{~mL}$, respectively. The PSA also demonstrated a sustained reduction from $8.3 \mathrm{ng} /$ $\mathrm{mL}$ at the start to $3.0 \mathrm{ng} / \mathrm{mL}$ at 24 months. Retreatment was required in only $2.9 \%$ of patients. ${ }^{17}$

\section{Holmium Laser Enucleation of the Prostate (HoLEP) - NE 1 GR A}

The Ho:YAG laser operates at 2,120 nm, with tissue water as the chromophore and its pulsed beam with high-energy concentration results in blisters leading to rupture of the prostatic tissue. Tissue penetration of the laser is only $0.4 \mathrm{~mm}$ in the prostate, which produces adequate coagulation and minimum carbonization. The physical properties of this laser allow its use in different tissues and stones. In the prostatic tissue, it can be used for ablation (HoLAP), resection (HoLRP) and enucleation (HoLEP), being that the latter is the most commonly used technique.

HoLEP has the largest number of randomized clinical trials compared with TURP and open prostatectomy than any other available laser technology. Based on a recent meta-analysis, the functional results are similar, and the catheter time and hospital stay were shorter in patients with HoLEP. ${ }^{18}$ It is also the only laser with long-term results published in the scientific literature in prospective and randomized studies. Compared with TURP, similar functional results were observed after an average of 7.6 years of follow-up. ${ }^{19}$

The need for morcellation of the prostatic tissue within the bladder at the end of the procedure and the 
long learning curve are the two main disadvantages of the method. According to a recent analysis, the rate of enucleation efficiency was significantly different between cohorts, and the threshold was generally observed after 50-60 cases conducted. Likewise, a significant difference is shown for efficiency of morcellation with stabilization in performance after 60 cases. ${ }^{20}$

To date, there is only one prospective, randomized study comparing HoLEP to the GL-XPS laser for the treatment of BPH. In it, 50 and 53 patients were included in the HoLEP and GL-XPS groups, respectively. Surgical time, hospital stay and catheter removal time were comparable between groups. There was a significant and comparable improvement in the score of symptoms and post-void residual test at 1, 4 and 12 months. After four months, the reduction of prostate size was significantly higher in the HoLEP group (74.3 vs. $43.1 \%$ ). At 12 months, the Qmax was significantly higher in the HoLEP group ( $26.4 \pm 11.5$ vs. $18.4 \pm 7.5 \mathrm{~mL} / \mathrm{s})$. Reintervention was required in two and three cases in the HoLEP and GL-XPS groups, respectively. The mean cost estimated for the HoLEP procedure was significantly lower than for the GL-XPS procedure. ${ }^{21}$

Faced with such facts, HoLEP has stood out as the technique used the most in North America and Europe and already appears in the guidelines of these societies as the first-line treatment.

\section{Simple PRostatectomy}

Patients diagnosed with infravesical obstruction (IVO) secondary to BPH with enlarged prostate $(>80 \mathrm{~mL})$ and moderate and severe IPSS symptoms present higher failure rates for drug therapy and disease progression, requiring more frequent surgical treatment. In these cases, the first-line surgical treatments recommended by the current guidelines of the EAU are: endoscopic enucleation with bipolar energy, endoscopic enucleation with HoLEP and simple open prostatectomy. ${ }^{13}$

Despite the emergence of new technologies, the standard treatment for large adenomas is still open simple prostatectomy (SP), due to the limited availability of these technologies in care centers and the advantage that open access offers when additional joint treatment is needed, such as cystolithotomy and bladder diverticulectomy. However, we know that SP is invasive and presents higher morbidity, with higher rates of bleeding and blood transfusion ranging from 7 to $14 \%,{ }^{22-24}$ bladder neck stenosis in up to $6 \%,{ }^{22,25,26}$ reintervention in up to $3.6 \%,{ }^{27}$ in addition to prolonged hospitalization time and bladder catheterization in the postoperative period, with higher occurrence the greater the prostate volume. ${ }^{28} \mathrm{~A}$ prospec- tive study showed a lower rate of intra- and postoperative bleeding as well as blood transfusion when the modified Millin technique was performed compared to conventional transvesical prostatectomy. ${ }^{29}$

Over the years, new endoscopic and video-assisted techniques have emerged to reduce morbidity in the standard open technique.

\section{VIDEO-ASSISTED SURGERY}

Video-assisted surgery involving the prostate was initiated in 1992 with Schuessler et al., ${ }^{30}$ who reported the first videolaparoscopy radical prostatectomy. Mariano et al. ${ }^{31}$ published the technique to perform simple laparoscopic radical prostatectomy (LRP) for BPH and in 2008 robot-assisted simple prostatectomy (RASP) was first reported. ${ }^{32}$ The term minimally invasive simple prostatectomy (MISP) refers to the LRP and RASP joint technique, which allows for transcapsular or transvesical adenomectomy either through extraperitoneal access, usually used in the LRP, or intraperitoneal, most commonly used in RASP.

\section{SiMPLE OPEN PROSTATECTOMY VS. SIMPLE LAPAROSCOPIC PROSTATECTOMY}

Comparing SP with LRP, a retrospective study did not demonstrate a significant difference in the incidence and severity of complications, with similar functional results. ${ }^{33}$ In a prospective and randomized study, similar functional results were described, but with rats bleeding less, and with statistical significance in the LRP using extraperitoneal access. ${ }^{34}$ Another prospective study involving 280 patients found statistically significant advantages for LRP, such as shorter hospital stay, shorter intravesical catheter time and lower rates of urinary tract infection. There was no difference regarding functional results; however, surgical time in the open procedure was shorter. ${ }^{35}$

\section{Simple OPEN PROSTATECTOMY VS. LAPAROSCOPIC SIMPLE PROSTATECTOMY VS. ROBOT-ASSISTED PROSTATECTOMY}

With the advent of robotic surgery in reference centers, new comparative studies are emerging between SP, LRP and RASP techniques.

In a recent meta-analysis, 27 studies involving 764 MISP (LRP and RASP) were evaluated, concluding that minimally invasive techniques have a longer surgical time, offer similar improvement in functional outcome, Qmax and IPSS compared to SP, with the advantage of having less blood loss and shorter hospital stay. ${ }^{36}$

The largest retrospective multicenter study evaluating minimally invasive techniques with 487 RASP and 843 LRP, 
totaling 1,330 patients in 23 American and European institutions, concluded that the functional results are similar, regardless of the technique used, with similar IPSS, Qmax and sexual function (Trifecta) in a 12-month follow-up. ${ }^{37}$

Current scientific evidence tends to qualify the feasible minimally invasive techniques as a safe and effective therapy for prostates with a volume above $80 \mathrm{~mL}$, with a level of evidence of 2A. ${ }^{13}$ However, many of these studies are retrospective and need to be validated by prospective randomized studies with long-term follow-up and comparative cost analyses between different endoscopic and conventional open techniques in order to corroborate not only the efficacy but also the effectiveness and reproducibility in other care centers.

As such, we can consider these different approaches as alternatives for treatment of enlarged prostates, with apparent similarity of efficacy and functional results. The new minimally invasive technologies are attractive options aimed at reducing morbidity, time of intravesical catheter use and hospitalization period, with reduction in the final cost of treatment, although still lacking scientific evidence to prove these benefits.

\section{Prostatic artery embolization (PAE)}

For more than 30 years, embolization of hypogastric arteries has been proposed to control severe prostatic hemorrhage with satisfactory results. ${ }^{38-40}$

In 2000, PAE was correlated for the first time with the relief of LUTS due to BPH in a patient with massive prostatic hematuria who had a surgical contraindication due to his clinical condition, submitted to the right super-selective PAE, and, after a 12 month follow-up period, presented a decrease of 11 points in the IPSS and a reduction of $40 \%$ in prostate volume and $90 \%$ in $P S A .{ }^{41}$ In the following years, other case reports and clinical series were described with super-selective PAE. ${ }^{39,40}$ However, only recently, following evidence in an experimental study in pigs, PAE has emerged as an option for the primary treatment of LUTS related to $\mathrm{BPH} .{ }^{42}$ The first two cases were described by Carnevale et al. ${ }^{43}$

The analysis of the clinical and urodynamic data of 11 patients with urinary retention due to BPO showed that spontaneous urination was obtained in ten of them (91\%) with an average follow-up of 22.3 months. However, according to the Bladder Obstruction Index, despite the statistically significant improvement in IPSS, QoL, Qmax and detrusor pressure, only one third of the patients were unobstructed postoperatively. ${ }^{44}$

To date, there is only one prospective, randomized study comparing TURP with PAE. This study analyzed 114 patients monitored for 24 months. Clinical failure rates were 3.9 and $9.4 \%$, respectively. Compared to the preoperative values, both treatments presented improvements at all times. However, TURP presented a higher degree of improvement in the IPSS, QoL, Qmax and RPM after 1 and 3 months in relation to the PAE group, as well as higher reductions for PSA and PV levels at all follow-up times. The PAE group had a greater number of adverse events and complications, mainly related to acute urinary retention (25.9\%) and post-embolization syndrome (11.1\%). ${ }^{45}$

A systematic review and recent meta-analysis evaluated the efficacy of PAE in LUTS caused by BPH in the short and medium term. A total of 484 patients from seven eligible studies were included. The mean differences in IPSS at 3, 6, 12 and 24 months were -14, -12, -16 and -17, respectively. Furthermore, mean Qmax, RPM, PV and QoL compared between the follow-up period and the baseline were significantly improved. ${ }^{46}$ Long-term studies are still needed to establish the actual efficacy of PAE for the treatment of BPH.

Certain complications have been reported to be associated with PAE. Among the 250 cases described in another study, $9.2 \%$ of patients had burning sensation in the urethra and/or anus during the procedure. Urinary tract infection occurred in $7.6 \%$, transient hematuria in $5.6 \%$, transitory hematospermia in $0.4 \%$, discreet rectal bleeding in $2.4 \%$, and balanitis in $1.6 \%$ of patients, all of which were selflimiting. Six patients had transient acute urinary retention after PAE. According to the authors, among 199 patients with IIEF follow-up data, the score improved in $48.2 \%$, remained stable in $21.6 \%$ and worsened in $30.2 \%$. There were no cases of sexual impotence or retrograde ejaculation. ${ }^{47}$

\section{NeW TECHNIQUES}

The search for new therapeutic modalities for any disorder is necessary and natural, even more so in times of rapid technological evolution. This is no different in the treatment of $\mathrm{BPH}$, and new options are already beginning to be established in clinical practice in accordance with the consolidation and scientific support for such. We currently have two innovative techniques that present promising experimental results and in early clinical trials.

Prostate ablation using hydrodissection uses a high-speed, robot-assisted, image-guided saline jet, requiring no electrical current or high temperature and the procedure, with greater accuracy in the target tissue, minimize bleeding and indirect effect in relevant adjacent structures such as the prostatic capsule, bladder neck and external sphincter, as well as potential preservation of ejaculatory function. ${ }^{48-51}$ 
Another promising technique is that of prostate hydration, which uses convective energy transfer properties (advantageous to conductive techniques) of steam over the defined space of the prostatic tissue (transition zone), reaching around $103{ }^{\circ} \mathrm{C}$ in the interstitial space and dispersed slowly and gently by the target tissue at temperatures up to $70-80^{\circ} \mathrm{C}$, causing instantaneous cell death (WAVE ${ }^{\circledR}$ technology). The procedure is performed via cystoscopy and a needle is inserted into each prostate lobe at a time for as many times as are necessary to cover the extent of the prostate mass. The vapor steam released for approximately nine seconds at a $120^{\circ}$ range circumferentially to the tip of the needle. The preliminary results of a single RCT comparing cystoscopy with a control and one year of follow-up in 197 men with BPH demonstrated significant reduction of IPSS and Qmax in the treated group, with no relevant adverse effects, except for one case of urinary retention resolved in the short term. ${ }^{52,53}$

Finally, the UroLift technique ${ }^{\circledR}$ (NE 1 GR B), which consists of minimally invasive implantation of clamps in the lateral prostatic lobes with retraction of such, allowed an increase of the prostatic urethra's lumen. It can be performed on an outpatient basis, presents a slightly inferior efficacy to the M- or B-TURP and HoLEP techniques, but with a much lower incidence of adverse effects, as well as significantly lower cost, thus constituting a considerable alternative for the surgical treatment of $\mathrm{BPH} .{ }^{54}$

\section{Resumo}

Tratamento cirúrgico contemporâneo da hiperplasia prostática benigna

A hiperplasia prostática benigna (HPB) é uma condição comum em homens adultos, de incidência progressiva com o envelhecimento, com importante impacto nas saúdes física e mental do indivíduo e história natural que pode levar a situações patológicas graves. Embora o tratamento inicial, salvo em situações específicas, seja farmacológico, a tendência de progressão da doença leva uma considerável parcela dos pacientes a necessitar do tratamento cirúrgico. Neste caso, existem diversas opções hoje disponíveis no arsenal terapêutico. Dentre estas, as técnicas consagradas, como as cirurgias por via aberta e a ressecção endoscópica por energia monopolar, ainda ocupam extenso terreno na escolha dos cirurgiões por serem mais acessíveis, tanto do ponto de vista socioeconômico na imensa maioria dos serviços médicos quanto do de aprendizado por parte das equipes médicas. Por outro lado, novas técnicas e tecnologias surgem sequencialmente no intuito de minimizar a agressão, o tempo cirúrgico, as complicações, bem como favorecer a recuperação, otimizando resultados em relação ao binômio eficácia/segurança. Cada uma destas tem seu próprio curso em relação à disponibilidade de acesso em decorrência de custo, curva de aprendizagem e consolidação científica, a fim de atingir conceituação e utilização de ponta no meio médico. O uso da energia bipolar na ressecção endoscópica da próstata, as técnicas de vaporização e enucleação a laser e a videolaparoscopia são exemplos de novas opções que trilharam esse caminho com sucesso. A cirurgia robô-assistida tem conquistado bastante espaço na última década, embora ainda esbarre na barreira comercial. Outras técnicas e tecnologias devem passar pelo crivo do tempo para poderem cavar espaço neste mercado que, tempo após tempo, torna-se mais vasto.

Palavras-chave: hiperplasia prostática benigna, tratamento cirúrgico, técnicas minimamente invasivas, laser, videolaparoscopia, cirurgia robô-assistida, bipolar.

\section{References}

1. Chute CG, Panser LA, Girman CJ, Oesterling JE, Guess HA, Jacobsen SJ, et al. The prevalence of prostatism: a population-based survey of urinary symptoms. J Urol. 1993; 150(1):85-9.

2. Verhamme KM, Dieleman JP, Bleumink GS, van der Lei J, Sturkenboom MC, Artibani W, et al.; Triumph Pan European Expert Panel. Incidence and prevalence of lower urinary tract symptoms suggestive of benign prostatic hyperplasia in primary care: the Triumph project. Eur Urol. 2002; 42(4):323-8.

3. Roehrborn CG. Current medical therapies for men with lower urinary tract symptoms and benign prostatic hyperplasia: achievements and limitations. Rev Urol. 2008; 10(1):14-25.

4. Gratzke C, Bachmann A, Descazeaud A, Drake MJ, Madersbacher S, Mamoulakis C, et al. EAU guidelines on the assessment of non-neurogenic male lower urinary tract symptoms including benign prostatic obstruction. Eur Urol. 2015; 67(6):1099-109.

5. Lourenco T, Armstrong N, N’Dow J, Nabi G, Deverill M, Pickard R, et al. Systematic review and economic modelling of effectiveness and cost utility of surgical treatments for men with benign prostatic enlargement. Health Technol Assess. 2008; 12(35): iii, ix-x, 1-146, 169-515.

6. Lourenco T, Pickard R, Vale L, Grant A, Fraser C, MacLennan G, et al.; Benign Prostatic Enlargement team. Alternative approaches to endoscopic ablation for benign enlargement of the prostate: systematic review of randomised controlled trials. BMJ. 2008; 337:a449.

7. Lourenco T, Pickard R, Vale L, Grant A, Fraser C, MacLennan G, et al.; Benign Prostatic Enlargement team. Minimally invasive treatments for benign prostatic enlargement: systematic review of randomised controlled trials. BMJ. 2008; 337:a1662.

8. Rassweiler J, Teber D, Kuntz R, Hofmann R. Complications of transurethral resection of the prostate (TURP): incidence, management, and prevention. Eur Urol. 2006; 50(5):969-79.

9. Mamoulakis C, Skolarikos A, Schulze M, Scoffone CM, Rassweiler JJ, Alivizatos $\mathrm{G}$, et al. Results from an international multicentre double-blind randomized controlled trial on the perioperative efficacy and safety of bipolar vs monopolar transurethral resection of the prostate. BJU Int. 2012; 109(2):240-8.

10. Mamoulakis C, Trompetter M, de la Rosette J. Bipolar transurethral resection of the prostate: the "golden standard" reclaims its leading position. Curr Opin Urol. 2009; 19(1):26-32.

11. Al-Rawashdah SF, Pastore AL, Salhi YA, Fuschi A, Petrozza V, Maurizi A, et al. Prospective randomized study comparing monopolar with bipolar transurethral resection of prostate in benign prostatic obstruction: 36-month outcomes. World J Urol. 2017; doi:10.1007/s00345-017-2023-7. 
12. Tang Y, Li J, Pu C, Bai Y, Yuan H, Wei Q, et al. Bipolar transurethral resection versus monopolar transurethral resection for benign prostatic hypertrophy: a systematic review and meta-analysis. J Endourol. 2014; 28(9):1107-14.

13. Gravas S, Bach T, Drake M, Gacci M, Gratzke C, Herrmann TRW, et al. Treatment of non-neurogenic male LUTS: EAU Guideline. 2017. Available from: http://uroweb.org/guideline/treatment-of-non-neurogenic-male-luts/

14. Malek RS, Kang HW, Coad JE, Koullick E. Greenlight photoselective 120watt 532-nm lithium triborate laser vaporization prostatectomy in living canines. J Endourol. 2009; 23(5):837-45.

15. Hueber PA, Liberman D, Ben-Zvi T, Woo H, Hai MA, Te AE, et al. 180 W vs $120 \mathrm{~W}$ lithium triborate photoselective vaporization of the prostate for benign prostatic hyperplasia: a global, multicenter comparative analysis of perioperative treatment parameters. Urology. 2013; 82(5):1108-13.

16. Thomas JA, Tubaro A, Barber N, d'Ancona F, Muir G, Witzsch U, et al. A multicenter randomized noninferiority trial comparing GreenLight-XPS laser vaporization of the prostate and transurethral resection of the prostate for the treatment of benign prostatic obstruction: two-yr outcomes of the GOLIATH Study. Eur Urol. 2016; 69(1):94-102.

17. Stone BV, Chughtai B, Forde JC, Tam AW, Lewicki P, Te AE. Safety and efficacy of GreenLight XPS laser vapoenucleation in prostates measuring over $150 \mathrm{~mL}$. J Endourol. 2016; 30(8):906-12

18. Cornu JN, Ahyai S, Bachmann A, de la Rosette J, Gilling P, Gratzke C, et al. A systematic review and meta-analysis of functional outcomes and complications following transurethral procedures for lower urinary tract symptoms resulting from benign prostatic obstruction: an update. Eur Urol. 2015; 67(6):1066-96.

19. Gilling PJ, Wilson LC, King CJ, Westenberg AM, Frampton CM, Fraundorfer MR. Long-term results of a randomized trial comparing holmium laser enucleation of the prostate and transurethral resection of the prostate: results at 7 years. BJU Int. 2012; 109(3):408-11.

20. Brunckhorst O, Ahmed K, Nehikhare O, Marra G, Challacombe B, Popert R. Evaluation of the learning curve for holmium laser enucleation of the prostate using multiple outcome measures. Urology. 2015; 86(4):824-9.

21. Elshal AM, Elkoushy MA, El-Nahas AR, Shoma AM, Nabeeh A, Carrier S, et al. GreenLight $^{\mathrm{TM}}$ laser (XPS) photoselective vapo-enucleation versus holmium laser enucleation of the prostate for the treatment of symptomatic benign prostatic hyperplasia: a randomized controlled study. J Urol. 2015; 193(3):927-34.

22. Kuntz RM, Lehrich K, Ahyai SA. Holmium laser enucleation of the prostate versus open prostatectomy for prostates greater than 100 grams: 5-year followup results of a randomised clinical trial. Eur Urol. 2008; 53(1):160-6

23. Varkarakis I, Kyriakakis Z, Delis A, Protogerou V, Deliveliotis C. Long-term results of open transvesical prostatectomy from a contemporary series of patients. Urology. 2004; 64(2):306-10.

24. Li M, Qiu G, Hou Q, Wang D, Huang W, Hu C, et al. Endoscopic enucleation versus open prostatectomy for treating large benign prostatic hyperplasia: a meta-analysis of randomized controlled trials. PLoS One. 2015; 10(3):e0121265.

25. Naspro R, Suardi N, Salonia A, Scattoni V, Guazzoni G, Colombo R, et al. Holmium laser enucleation of the prostate versus open prostatectomy for prostate > $70 \mathrm{~g}$ : 24-months follow up. Eur Urol. 2006; 50(3):563-8.

26. Tubaro A, Carter S, Hind A, Vicentini C, Miano L. A prospective study of the safety and efficacy of suprapubic transvesical prostatectomy in patients with benign prostatic hyperplasia. J Urol. 2001; 166(1):172-6.

27. Serretta V, Morgia G, Fondacaro L, Curto G, Lo bianco A, Pirritano D, et al.; Members of the Sicilian-Calabrian Society of Urology. Open prostatectomy for benign prostatic enlargement in southern Europe in the late 1990s: a contemporary series of 1800 interventions. Urology. 2002; 60(4):623-7.

28. Elshal AM, El-Nahas AR, Barakat TS, Elsaadany MM, El-Hefnawy AS. Transvesical open prostatectomy for benign prostatic hyperplasia in the era of minimally invasive surgery: perioperative outcomes of a contemporary series. Arab J Urol. 2013; 11(4):362-8.

29. Dall'Oglio MF, Srougi M, Antunes AA, Crippa A, Cury J. An improved technique for controlling bleeding during simple retropubic prostatectomy: a randomized controlled study. BJU Int. 2006; 98(2):384-7.

30. Schuessler WW, Kavoussi LR, Clayman RV, Vancaille TH. Laparoscopic radical prostatectomy: initial case report. J Urol. 1992; 147:246A.

31. Mariano MB, Graziottin TM, Tefilli MV. Laparoscopic prostatectomy for vascular control for benign prostatic hyperplasia. J Urol. 2002; 167(6):2528-9.

32. Sotelo R, Clavijo R, Carmona O, Garcia A, Banda E, Miranda M, et al. Robotic simple prostatectomy. J Urol. 2008; 179(2):513-5

33. Baumert H, Ballaro A, Dugardin F, Kaisary AV. Laparoscopic versus open simple prostatectomy: a comparative study. J Urol. 2006; 175(5):1691-4.
34. Porpiglia F, Terrone C, Renard J, Grande S, Musso F, Cossu M, et al. Transcapsular adenomectomy (Milin): a comparative study, extraperitoneal laparoscopic versus open surgery. Eur Urol. 2006; 49(1):120-6.

35. McCullough TC, Heldwein FL, Soon SJ, Galiano M, Barret E, Cathelineau $\mathrm{X}$, et al. Laparoscopic versus open simple prostatectomy: an evaluation of morbidity. J Endourol. 2009; 23(1):129-33.

36. Lucca I, Shariat SF, Hofbauer SL, Klatte T. Outcomes of minimally invasive simple prostatectomy for benign prostatic hyperplasia: a systematic review and meta-analysis. World J Urol. 2015; 33(4):563-70.

37. Autorino R, Zargar H, Mariano MB, Sanchez-Salas R, Sotelo RJ, Chlosta PL, et al. Perioperative outcomes of robotic and laparoscopic simple prostatectomy: a European-American multi-institutional analysis. Eur Urol. 2015; 68(1):86-94.

38. Mitchell ME, Waltman AC, Athanasoulis CA, Kerr WS Jr, Dretler SP. Control of massive prostatic bleeding with angiographic techniques. J Urol. 1976; 115(6):692-5

39. Barbieri A, Simonazzi M, Marcato C, Larini P, Barbagallo M, Frattini A, et al. Massive hematuria after transurethral resection of the prostate: management by intra-arterial embolization. Urol Int. 2002; 69(4):318-20.

40. Michel F, Dubruille T, Cercueil JP, Paparel P, Cognet F, Krause D. Arterial embolization for massive hematuria following transurethral prostatectomy. J Urol. 2002; 168(6):2550-1.

41. DeMeritt JS, Elmasri FF, Esposito MP, Rosenberg GS. Relief of benign prostatic hyperplasia-related bladder outlet obstruction after transarterial polyvinyl alcohol prostate embolization. J Vasc Interv Radiol. 2000; 11(6):767-70.

42. Sun F, Sánchez FM, Crisóstomo V, Lima JR, Luis L, García-Martínez V, et al Benign prostatic hyperplasia: transcatheter arterial embolization as potential treatment: preliminary study in pigs. Radiology. 2008; 246(3):783-9.

43. Carnevale FC, Antunes AA, Motta Leal Filho JM, Oliveira Cerri LM, Baroni $\mathrm{RH}$, Marcelino AS, et al. Prostatic artery embolization as a primary treatment for benign prostatic hyperplasia: preliminary results in two patients. Cardiovasc Intervent Radiol. 2010; 33(2):355-61.

44. Antunes AA, Carnevale FC, da Motta Leal Filho JM, Yoshinaga EM, Cerri LM, Baroni RH, et al. Clinical, laboratorial, and urodynamic findings of prostatic artery embolization for the treatment of urinary retention related to benign prostatic hyperplasia. A prospective single-center pilot study. Cardiovasc Intervent Radiol. 2013; 36(4):978-86.

45. Gao YA, Huang Y, Zhang R, Yang YD, Zhang Q, Hou M, et al. Benign prostatic hyperplasia: prostatic arterial embolization versus transurethral resection of the prostate: a prospective, randomized, and controlled clinical trial. Radiology. 2014; 270(3):920-8.

46. Pyo JS, Cho WJ. Systematic review and meta-analysis of prostatic artery embolisation for lower urinary tract symptoms related to benign prostatic hyperplasia. Clin Radiol. 2017; 72(1):16-22.

47. Pisco JM, Rio-Tinto H, Campos Pinheiro L, Bilhim T, Duarte M, Fernandes $\mathrm{L}$, et al. Embolisation of prostatic arteries as treatment of moderate to severe lower urinary symptoms (LUTS) secondary to benign hyperplasia: results of short- and mid-term follow-up. Eur Radiol. 2013; 23(9):2561-72.

48. Faber K, Abreu AL, Ramos P, Aljuri N, Mantri S, Gill I, et al. Image-guided robotassisted prostate ablation using water jet-hydrodissection: initial study of a novel technology for benign prostatic hyperplasia. J Endourol. 2015; 29(1):63-9.

49. Pimentel MA, Nair SM, Gilling PJ. Aquablation ${ }^{\mathrm{TM}}$ : early clinical results. Curr Bladder Dysfunct Rep. 2016; 11(2):130-3.

50. Gilling P, Reuther R, Kahokehr A, Fraundorfer M. Aquablation - imageguided robot-assisted waterjet ablation of the prostate: initial clinical experience. BJU Int. 2016; 117(6):923-9.

51. Gilling P, Anderson P, Tan A. Aquablation of the prostate for symptomatic benign prostatic hyperplasia: 1-year results. J Urol. 2017; 197(6):1565-72.

52. Dixon CM, Rijo Cedano E, Mynderse LA, Larson TR. Transurethral convective water vapor as a treatment for lower urinary tract symptomatology due to benign prostatic hyperplasia using the Rezüm(®) system: evaluation of acute ablative capabilities in the human prostate. Res Rep Urol. 2015; 7:13-8.

53. McVary KT, Gange SN, Gittelman MC, Goldberg KA, Patel K, Shore ND, et al. Minimally invasive prostate convective water vapor energy ablation: a multicenter, randomized, controlled study for the treatment of lower urinary tract symptoms secondary to benign prostatic hyperplasia. J Urol. 2016; 195(5):1529-38.

54. Ray A, Morgan H, Wilkes A, Carter K, Carolan-Rees G. The Urolift System for the treatment of lower urinary tract symptoms secondary to benign prostatic hyperplasia: a NICE medical technology guidance. Appl Health Econ Health Policy. 2016; 14(5):515-26. 